The

Connecticut

\title{
Control of
}

Cabomba and

Agricultural

Experiment

Station,

New Haven

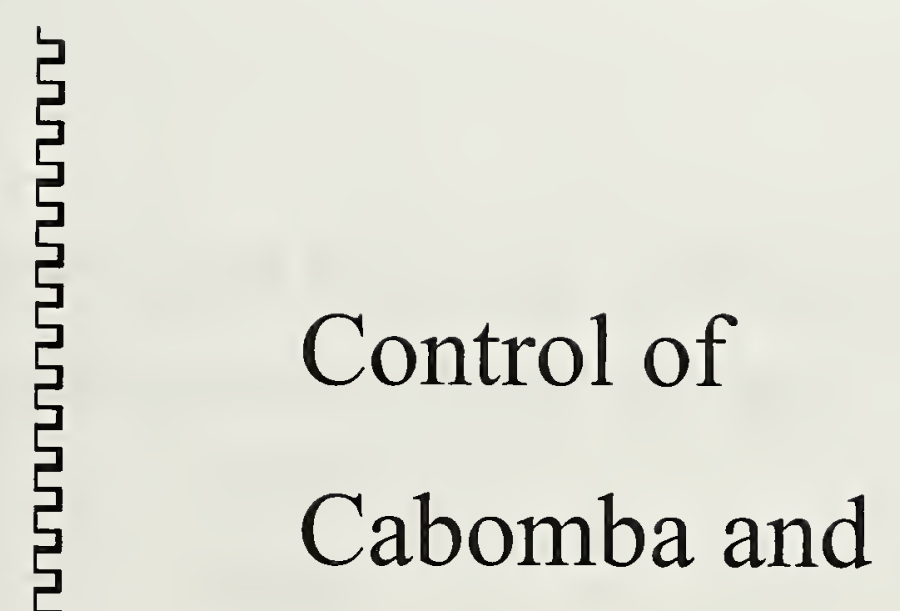

Eurasian Milfoil

in Lake

Quonnipaug with

Fluridone and

2,4-D

2001

BY GREGORY J. BUGBEE

AND JASON C. WHITE

Bulletin 998

June 2005 
Digitized by the Internet Archive in 2011 with funding from LYRASIS members and Sloan Foundation 


\title{
Control of Cabomba and Eurasian Milfoil in Lake Quonnipaug with Fluridone and
}

\author{
2,4-D \\ 2001
}

\author{
BY GREGORY J. BUGBEE \\ AND JASON WHITE
}

\section{INTRODUCTION}

Lake Quonnipaug is a 112-acre lake located in Guilford Connecticut. It has a maximum depth of 48 feet and an average depth of 14 feet. The lake is accessible to state residents via the town beach and the boat launch ramp. Aquatic vegetation in the lake has increased rapidly in recent years, and recreational uses are threatened. The introduction of the invasive exotic weeds, Eurasian milfoil (Myriophyllum spicatum), variable milfoil (Myriophyllum heterophyllum) and cabomba (Cabomba caroliniana), have made the problem more acute because these plants can spread rapidly and crowd out existing vegetation (Madsen et al., 1991). A threatened plant species called water marigold (Megalodonta beckii) and a desirable low growing plant called robbins pond weed (Potamogeton robbinsii) also inhabit the lake. Any control of invasive weeds must protect these nontarget plants.

Studies on the history of aquatic vegetation in Connecticut lakes are scarce. The first surveys of Connecticut lakes were performed as part of the states fisheries management program in the 1930s and 1950s (CT State Board of Fisheries and Game, 1942 and 1959). These surveys provide general information on the presence of aquatic vegetation but fail to identify the species of plants found. The 1930s study indicated that of the 44 lakes and ponds observed, 27 were classified as having either "extensive," "luxuriant," "considerable," or "dense" growths of aquatic weeds. In the 1950s, 89 of the 151 water bodies examined were classified as having large areas of aquatic vegetation. The Connecticut Agricultural Experiment Station (CAES) performed the most complete inventory of aquatic vegetation in Connecticut lakes in the 1970 s (Frink and Norvell, 1984). Although the main goal of this work was to determine water chemistry, the coverage and species of plants found were detailed. Of the 70 lakes studied, 33 were noted as having either "abundant" or "dense" growths of aquatic weeds. Unfortunately, a follow-up study 20 years later by investigators at Connecticut College did not address aquatic vegetation (Canavan and Siver, 1995), and more recent trends cannot be quantified. Neither milfoil nor cabomba was present in Connecticut in the mid 1900s (Muenscher, 1944). The first report of milfoil occurred in Little Pond, in Thompson CT, during the 1950s (CT State Board of Fisheries and Game, 1959). By the 1970s, eleven Connecticut lakes contained milfoil and five contained cabomba (Frink and Norvell, 1984).

Past efforts to study water chemistry in Connecticut lakes were based on the premise that increases in key nutrients such as phosphorus $(\mathrm{P})$ and nitrogen (N) lead to the growth of algae that degrades lakes. Algae is limited mainly by the amount of phosphorus in the water (Vallentyne, 1974). Past concerns over increases in algal blooms have largely been replaced by worries over the spread of invasive rooted aquatic vegetation. Unlike algae, the growth of aquatic weeds has not been well correlated with concentrations of nutrients in water. Aquatic weeds obtain a large proportion of their nutrients from the sediment and can flourish in nutrient poor water. Work by Bristow and Whitcombe (1971) found Eurasian milfoil obtained $60-90$ percent of its phosphorus from the sediment. 
Reducing nutrient inputs into the lake by watershed management is important and may limit algae, but may not reduce aquatic weeds. In addition, non-point nutrients can be extremely difficult to reduce because of the diffuse nature of the sources (Duggan et al., 1997).

Controls for aquatic weeds include: sediment removal (dredging), water level drawdown, harvesting, biological controls, bottom barriers and herbicides (Cooke et al., 1986). Dredging removes nutrients in the sediment, positions the lake bottom below where light can support plant growth and returns the lake to conditions similar to those at its inception. It can be an excellent longterm solution, but it is impractical for most large lakes. Sediment removal is disruptive to lake ecology. Partial dredging or removal of sediment to an insufficient depth often yields disappointing results. Approximately 60 acres of 960-acre Bantam Lake, in Litchfield CT, were dredged from 1982 to 1990 . About 370,000 cubic yards of sediment were removed at a cost of 1.7 million dollars (Baystate Environmental Consultants, Inc., 1992). Although some weed control was achieved, many areas of weeds remained in undredged areas and locations not dredged to sufficient depth. Water level drawdown can be effective if weeds are allowed to freeze or dry, but this has adverse effects on nontarget aquatic organisms. Weed control by winter drawdown can be affected by weather. Some weeds, like milfoil, have seeds or other plant parts that can survive substantial drying (Standifer and Madsen, 1997). Drawdown is not possible in Lake Quonnipaug because the dam does not have a deep discharge outlet. Even if a new dam was installed, the drop needed to facilitate a deep drawdown appears inadequate. Harvesting or mechanical removal has the benefit of providing immediate control, but problems include rapid regrowth, finding suitable disposal sites and spreading of weeds by fragmentation (Cooke et al., 1986). Weeds like milfoil spread by the rooting of broken pieces (Madsen et al., 1988) and harvesting practices can distribute the weed throughout a lake.

Considerable efforts have been made to find biological controls for lake weeds. Plant-eating fish, called grass carp (Ctenopharyngodon idella), can effectively reduce the populations of certain aquatic weeds. Unfortunately, these fish are often considered inappropriate because their feeding is not selective and desirable plants can be eliminated. In addition, if the fish breed in Connecticut, they could move to other lakes where populations of desirable native plants could be destroyed. Attempts to find plant pathogens and insects that control nuisance aquatic plants are ongoing. Some appear promising but there is little likelihood they will play a major role in the reduction of aquatic weeds soon (Cooke et al., 1986). Aquatic herbicides can control or suppress aquatic weeds with minimal effects on a lake's ecosystem. Spot applications are preferable to whole lake treatments because chemical usage is reduced, areas containing desirable plants are avoided, and exposure to humans and wildlife is minimized. Spot treatments can also eliminate troublesome vegetation near boat launch ramps where weeds become attached to boat trailers and get transported to other lakes. The most widely used aquatic herbicides in Connecticut are Sonar (fluridone), Reward (diquat) and Navigate (2,4D). Fluridone and 2,4-D are translocated throughout the entire plant, causing dieback of the roots and shoots. Diquat destroys only foliage and regrowth from the roots is likely. Sonar is commonly applied as a liquid (Sonar AS) to lakes. Weeds must be exposed to adequate concentrations of this herbicide for many weeks and, therefore, whole lake treatments are customary. A pelletized form of Sonar (Sonar SRP) is labeled for spot treatments. Successful use of Sonar SRP is poorly documented but anecdotal evidence suggests poor results are common. The only other systemic herbicide for spot treatment is 2,4-D. Although, effective against weeds like milfoil, it has not been shown to control cabomba. Information is needed on the effectiveness of spot-treated herbicides on weeds like cabomba, their effects on non-target plants like water marigold and their persistence and movement in the environment. 


\section{Sites for Spot Treatments 2001}

Gregory J. Bugbee

CT Agricultural Experiment Station Department of Soil and Water 123 Huntington Street P.O. Box 1106 New Haven, CT 06504

\section{Town Beach 2,4-D Treatment Area}

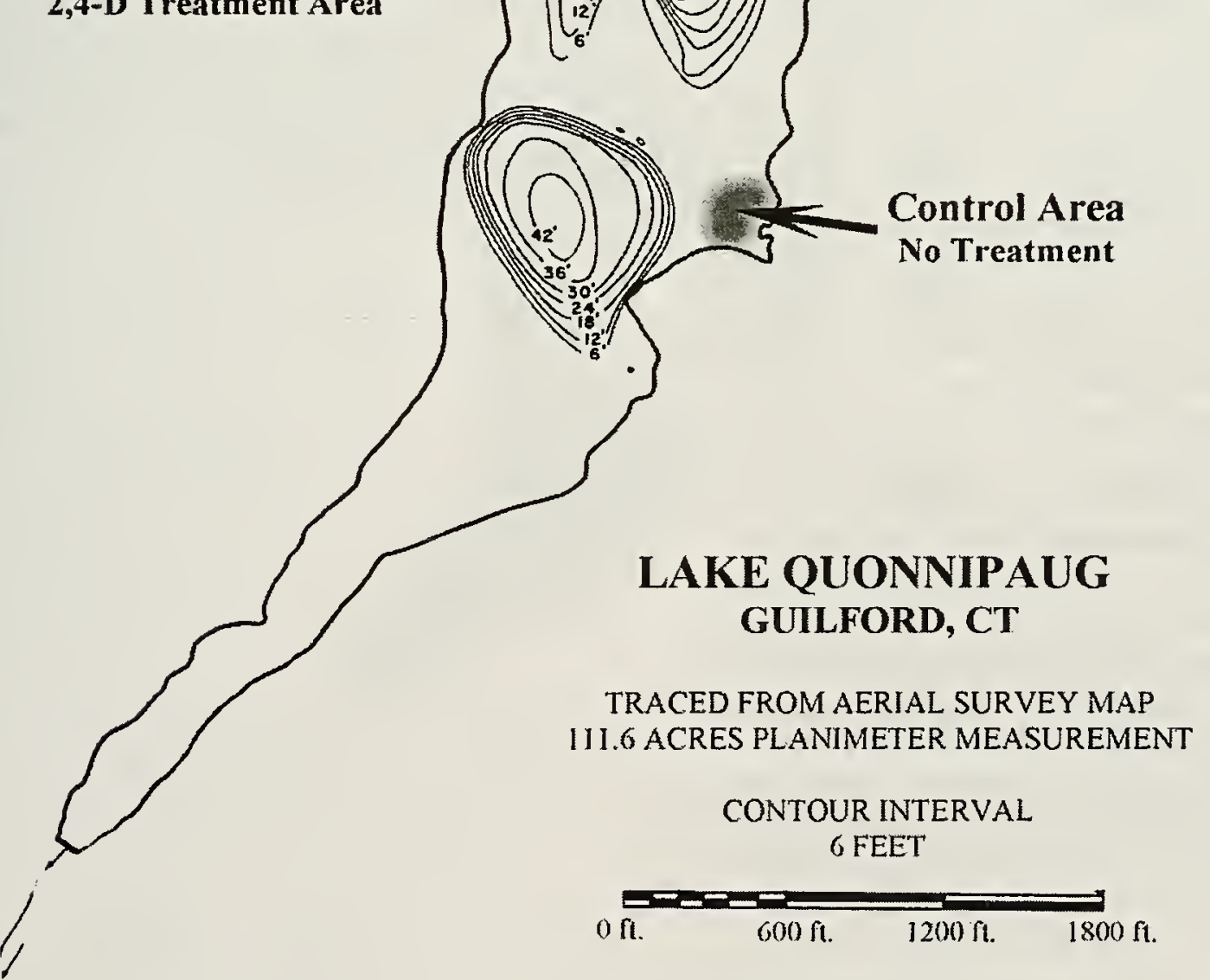




\section{OBJECTIVES}

1. Determine if localized areas of cabomba, milfoil, and large leaf pondweed can be controlled with spot applications of Sonar SRP. Quantify fluridone concentrations in lake water and monitor effects on non-target aquatic vegetation such as water marigold and robbins pondweed.

2. Determine the effectiveness of spot applications of granular 2,4-D (Navigate) on the control of Eurasian milfoil and cabomba. Quantify 2,4-D concentrations in lake water and determine the time needed to lift irrigation restrictions. Quantify the effects of 2,4-D on nontarget plants such as water marigold and robbins pondweed.

\section{MATERIALS AND METHODS}

Meetings were held with officials from the Town of Guilford, local residents and Connecticut Department of Environmental Protection (CTDEP) to discuss the weed control options. A decision was made to test the use of spot applications of aquatic herbicides to control cabomba in the boat launch area and Eurasian water milfoil in the vicinity of the town beach. A research grant was provided by the Town of Guilford, CT to support this work. A pretreatment survey for water marigold (with Nancy Murray, CTDEP) was performed on May 15, 2001 and a general aquatic vegetation survey was done on May 17, 2001. CAES applied to CTDEP, in March 2001, for a permit to use 80 pounds of Sonar SRP (slow release pellets) and 200 pounds of Navigate. The permit was granted on May 11, 2001. In June, CAES was granted permission from CTDEP to purchase another 40 pounds of Sonar SRP. Locations for the spot treatments are shown on the map "Sites for Spot Treatment Areas 2001." A control area containing milfoil, cabomba and pondweed was located in a cove on the central eastern shore. This area was designated to be left untreated to monitor the growth of the weeds likely to be unaffected by treatments and quantify movement of the herbicides. Based upon advice from the manufacturer, Sonar SRP was applied in four weekly applications of $15 \mathrm{lbs} / \mathrm{A}$. The goal was to maintain fluridone concentrations of $5-10 \mathrm{ppb}$ for several weeks. Information supplied by SePro, Inc. suggested weed control could be effective with lower levels of fluridone because of interactions of the fluridone with the sediment and possible root uptake.
Navigate was applied at a rate equivalent to 150 pounds per acre to Eurasian milfoil near the town beach on May 24, 2001. A follow-up treatment $50 \mathrm{lbs} /$ A Navigate was made on June 6 . The goal was to achieve 2,4-D concentrations of $1000 \mathrm{ppb}$ for at least 24 hours. On June 15,2001 , an electric weed cutter was used to remove remaining milfoil from the beach area.

The public was notified of the herbicide applications the week preceding the May 24th treatments. Newspaper notification occurred in the Shoreline Times and handouts were given to lakefront landowners. Signs were also posted at the town beach and boat launch ramp. Notification protocol was pursuant to Section $22 \mathrm{a}-66 \mathrm{a}(\mathrm{g})$ of the CT General Statutes.

Lake water samples for herbicide analysis were obtained from the center of the treatment sites, 100 feet away from the sites and in the control site $(>1000$ feet away). Samples were collected 1 day after treatment and weekly thereafter until mid September. Water was tested for 2,4-D by solid phase extraction (SPE) and liquid chromatography (LC) with a detection limit of $1 \mathrm{ppb}$. Fluridone testing was by SPE and LC (detection limit of $0.25 \mathrm{ppb}$ ) at CAES and immunoassays at SePro Corp (Bugbee and White, submitted for publication). 


\section{Aquatic Plant Survey May 17, 2001}

Gregory J. Bugbee Jason C. White

CT Agricultural Experiment Station Department of Soil and Water 123 Huntington Street P.O. Box 1106 New Haven, CT 06504

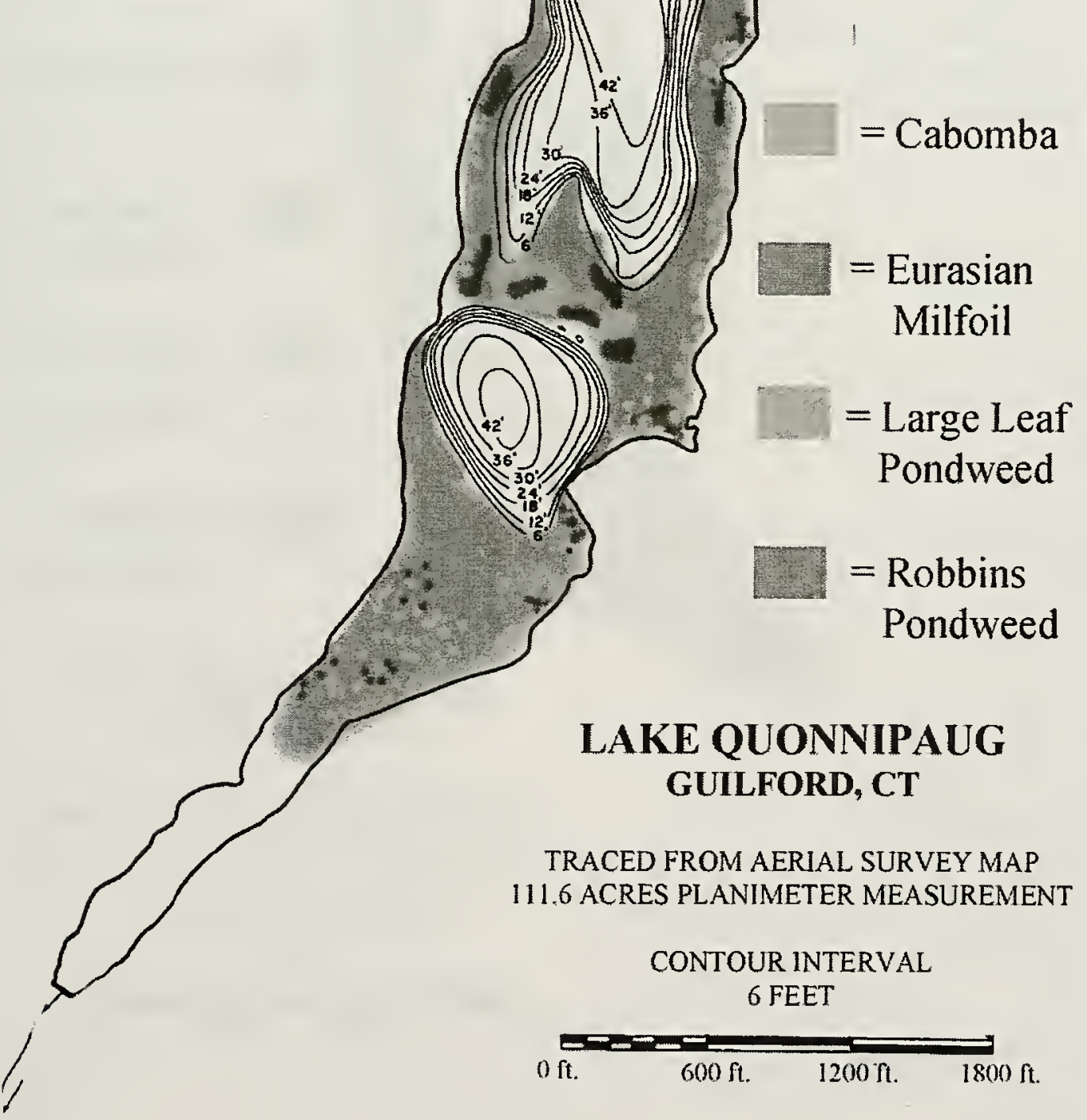




\section{Aquatic Plant Survey July 30, 2001}

Gregory J. Bugbee Jason C. White

Assisted by:

Jessica Dombroski

Lydia Wagner

Butch Johnson

Mike Annino

CT Agricultural Experiment Station Department of Soil and Water 123 Huntington Street P.O. Box 1106 New Haven, CT 06504

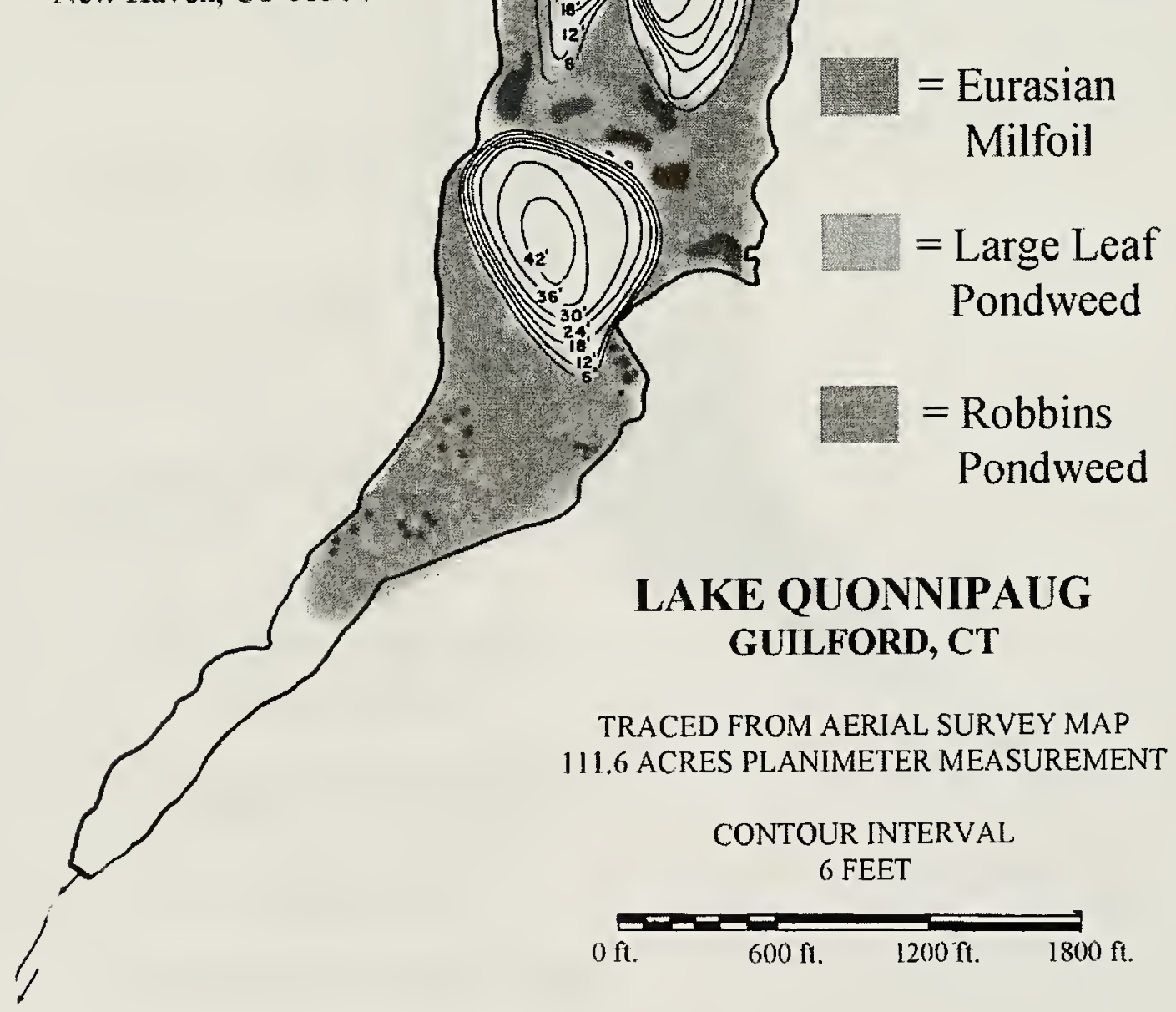




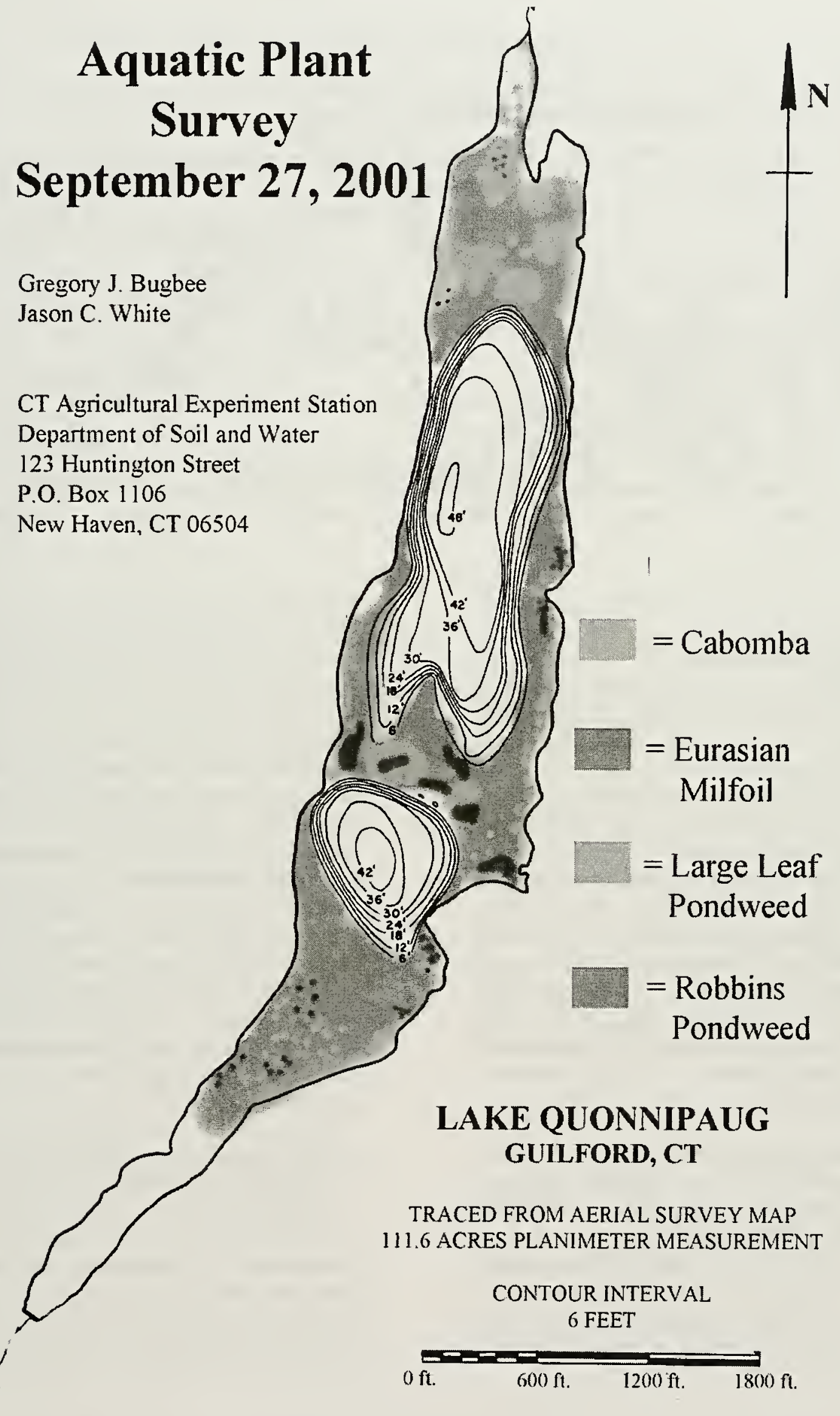


Figure 1. Sonar Concentrations Lake Quonnipaug.

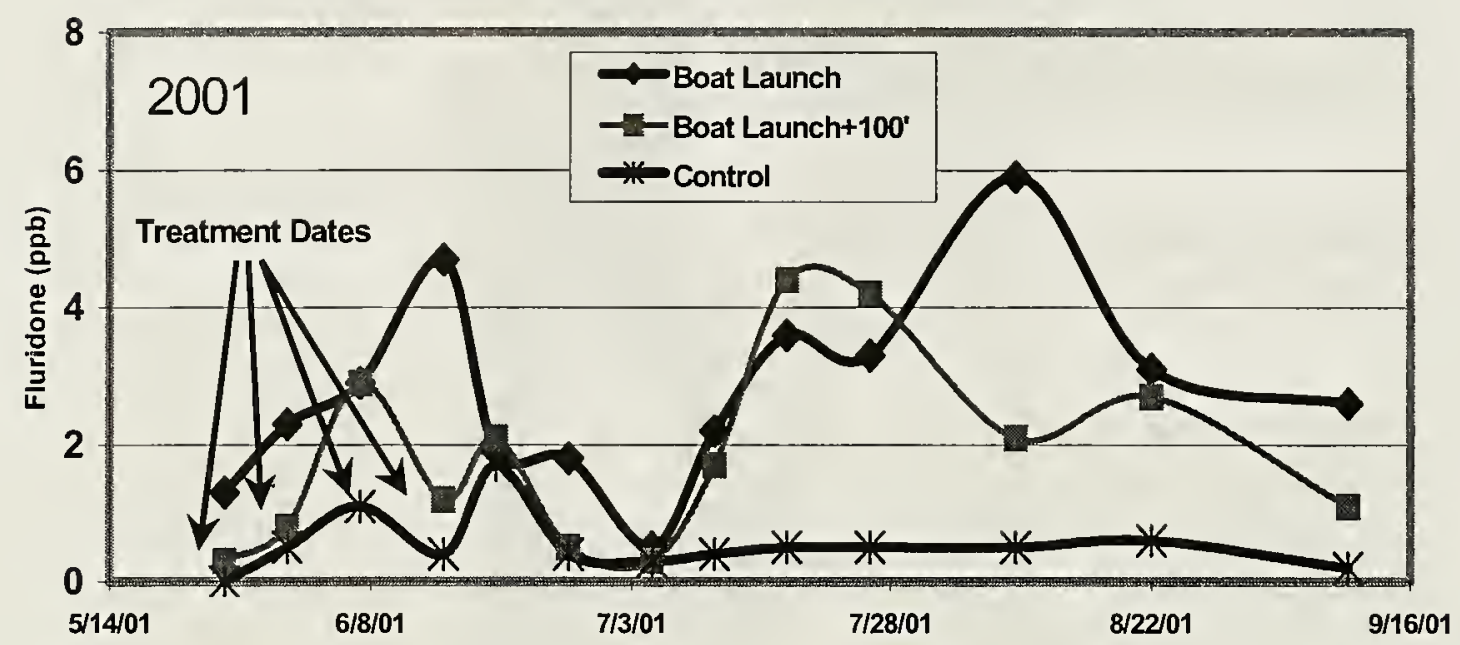

\section{RESULTS AND DISCUSSION}

The May 15 and 17, 2001 pretreatment aquatic vegetation surveys found no water marigold. Water marigold is usually more visible later in the season. Most of the bottom between 1 and 3 meters deep was covered with robbins pondweed. Large patches of cabomba, Eurasian milfoil and large leaf pondweed were also present (see Aquatic Plant Survey Map, May 17, 2001). Cabomba was densest in the boat launch cove and the coves on the southeast shore. Eurasian milfoil was most prevalent in the vicinity of the town beach and the shallows near the center of the lake. Large leaf pondweed was found in dense patches along the northern, eastern and southern shores. All the aforementioned plants were sporadically present in other shallow portions of the lake. Areas of dense lily pads were not surveyed.

The Sonar treatments to the boat launch cove initially yielded disappointing results. By July 30 (see Aquatic Plant Survey, July 30, 2001), some yellowing and decline in plant vigor was noted but weed control was negligible. Water tests suggested that fluridone levels (Figure 1) were below the desired 5-10 ppb range. By mid-August, fluridone concentrations unexpectedly began to rise and weed decline accelerated. By mid-
September, the cabomba in the boat launch treatment sites was nearly gone. Untreated cabomba in the southeast coves was vibrant, thus confirming that the dieback of the treated cabomba was not related to the change in season. The bottom in the treated areas was largely free of vegetation, suggesting that control of robbins pond weed, and Eurasian milfoil had also occurred. Lily pads in the shallows of the boat launch area were thinned and stunted. Water tests for fluridone adjacent to the treated boat launch (boat launch $+100^{\prime}$ ) showed significant levels of fluridone. Although the cabomba in this area was stunted and yellow, control was incomplete. Whether these areas will recover is unknown. Effects on robbins pondweed in the area adjacent to the boat launch treatment site were minimal.

Reasons for the slow release of the Sonar and the corresponding abnormally slow decline of the cabomba warrant discussion. The reason for the split application of Sonar over a four-week period was to counteract quick release of fluridone from the pellets and rapid movement out of the treatment area. In fact, the fluridone release was too slow in the water. Reasons for this could be related to the formulation of the pellets 


\section{Figure 2. 2,4-D concentrations Lake Quonnipaug.}

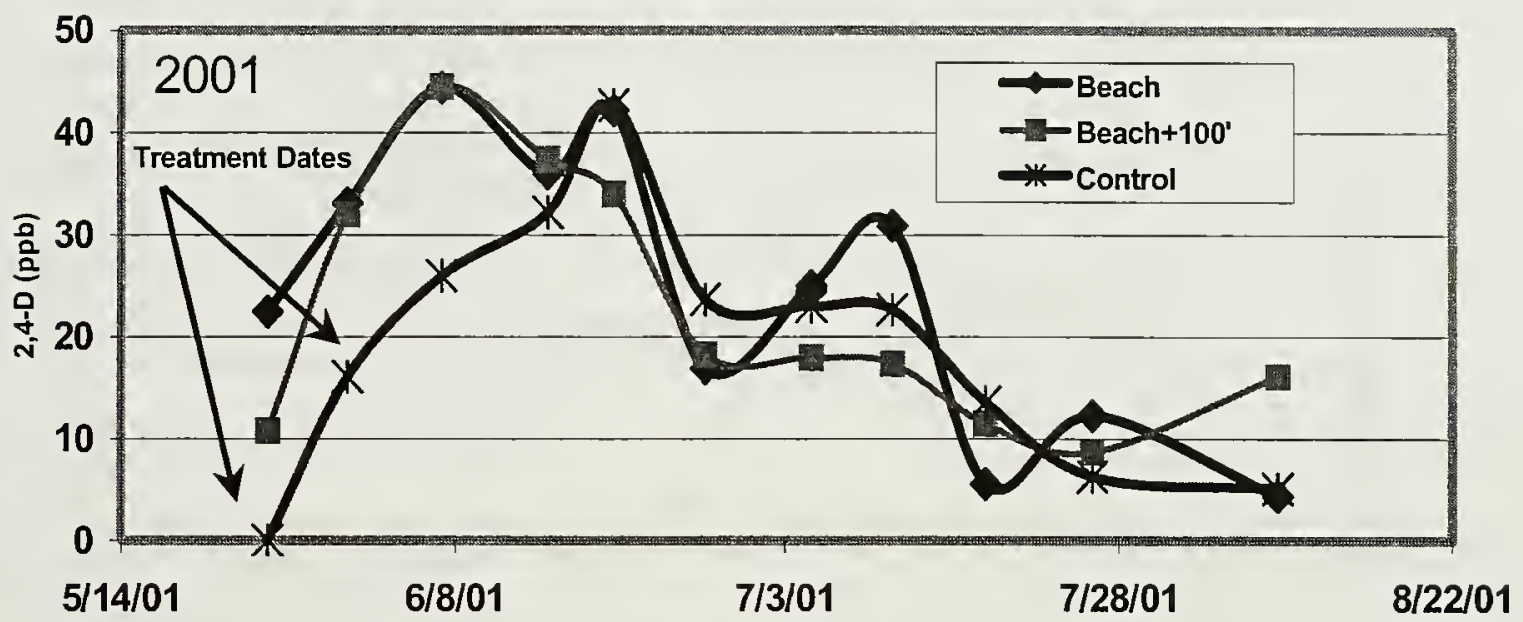

or reactions between the fluridone and the highly organic sediment. A new formulation of Sonar SRP, which releases faster in areas where the sediment is high in organic matter, was recently introduced by SePro, Inc.

The May 24 Navigate treatment near the town beach resulted in a slower than expected decline in the milfoil. After two weeks, the milfoil looked healthy except for some slight elongation and distortion of the growing tips. This slow decline, combined with the water tests that showed much lower than optimal concentrations of 2,4-D (Figure 2) in the treatment area, resulted in a follow-up application of Navigate on June 7. By June 15th, the treated milfoil was declining but still a hazard to swimmers. With the opening of the beach imminent, an electric weed cutter was used to clear the swimming area of the milfoil. The July 30 th and September 27 th aquatic plant surveys found no regrowth of milfoil in sandy bottom in the majority of the treated area. Sporadic cabomba found in the beach area during the May survey was also gone.

Movement of the herbicides throughout the lake was documented. 2,4-D was found at concentrations approaching that of the treated area in both the control site and the boat launch cove. No levels of 2,4-D exceeded the irrigation standard of $100 \mathrm{ppb}$.
Movement of 2,4-D may have been accelerated because of the exposed central location of the treatment site. Fluridone was also found in the control area. Except for two occasions in June, where fluridone concentrations were between 1 and $2 \mathrm{ppb}$, all levels were below $1 \mathrm{ppb}$.

Based on dissolved oxygen tests of treated and untreated areas (control sites), we determined that water in the boat launch site had greater dissolved oxygen when the cabomba was actively growing (Figure 3) and much lower oxygen when the cabomba was in the state of decline. This might be due to the production of oxygen by healthy plants and the consumption of oxygen during plant decay. A similar reduction in dissolved oxygen was not observed in the treated area by the beach. This is probably a result of better circulation of water and that much of the milfoil was cut and drifted away before it could decay.

Tests of water temperature, $\mathrm{pH}$, alkalinity and clarity found $\mathrm{pH}$ 's ranged from 6.2-7.8, alkalinities between 29-49 $\mathrm{mg} / \mathrm{L} \mathrm{CaCO}_{3}$ and clarity from 2-5 meters. The clearest water occurred in September. No effects on these water properties could be attributed to the herbicide treatments. 
Figure 3. Dissolved oxygen at $0.5 \mathrm{~m}$ depth in Lake Quonnipaug.



\section{CONCLUSIONS}

Spot treatments of cabomba with Sonar SRP and Eurasian milfoil can provide local control of the weeds. Control of cabomba will be slow with a noticeable decline in growth taking about three months. Splitting the applications over a four-week period is probably not necessary. The new formulation of Sonar SRP may provide different results. Regrowth in treated areas needs time to be assessed. Navigate can be used to successfully remove Eurasian milfoil from areas in Lake Quonnipaug. Milfoil control will take over 4 weeks. Use of lake water for irrigation after a localized treatment is not likely to be a problem. The affects of the herbicide treatment on water marigold could not be assessed because of the inability to locate the plant prior to treatment.

\section{ACKNOWLEDGMENTS}

The assistance of the following individuals is gratefully acknowledged.

Mr. Mike Annino, Southern Connecticut College

Ms. Jessica Dombroski, Department of Soil and Water, CAES

Mr. Ed Finger, Lake Manager, Lake Quonnipaug, Guilford, CT

Dr. Charles Frink, Department of Soil and Water, CAES

Dr. Kurt Gedsinger, United States Army Corps of Engineers

Dr. Evelyn Haviar, Department of Biochemistry and Genetics, CAES

Mr. Bill Johnson, Chairman, Guilford Conservation Commission

Mr. Butch Johnson, Southern Connecticut College

Dr. George Knoecklein, Northeast Aquatic Research, Mansfield Center, CT

Mr. Chuck Lee, Bureau of Planning and Standards, CTDEP

Ms. Nancy Murray, Natural Diversity Data Base, CTDEP

Ms. Linda Nelson, United States Army Corps of Engineers, Vicksburg, MS 
Mr. Brad Robinson, Pesticide Control, CTDEP

Dr. Jerry Silbert, Guilford Conservation Commission

Ms. Judy Singer, Pesticide Control, CTDEP

Mr. Gerry Smith, Aquatic Control Technologies, Sutton, MA

Ms. Joan Stettbacher, 5 Cheryl Lane, Guilford, CT

Mr. Ben Sylvester, 114 Quonnipaug Lane, Guilford, CT

Ms. Lydia Wagner, Department of Soil and Water, CAES

The Town of Guilford and the United States Department of Agriculture, through Hatch Grant CONH00771, supplied funding for this research.

\section{REFERENCES}

Bugbee, G.J. and J.C. White. Control of Cabomba caroliniana in Lake Quonnipaug, CT with spot applications of fluridone (Sonar SRP). J. Aquatic Plant Manag., submitted for publication.

Bristow, J.M. and M. Whitcombe. 1971. The role of roots in the nutrition of aquatic vascular plants. Amer. J. Bot., 58:8-13.

Duggan, J.X., GJ. Bugbee and B.E. Brennan. 1997. Volunteer water monitoring in lakes: A case study. American Environmental Laboratory. 3/97: $1-9$

Canavan IV, R.W. and P.A. Siver. 1995. Connecticut Lakes: A study of the chemical and physical properties of fifty-six Connecticut Lakes. Connecticut College Arboretum. New London, CT.

Cooke, G.D., E.B. Welch, S.A. Peterson and P.R. Newroth. 1986. Lake and Reservoir Restoration. London. Butterworths Press

Frink, C.R. 1969. Chemical and mineralogical characteristics of eutrophic lake sediments. Soil Sci. Soc. Am. Proc. 33:326-328

Siver, P.A., R.W. Canavan IV, C.K. Field, L.J. Marsicano and A.M. Lott. Estimating the effects of changing land use patterns on Connecticut lakes. J. Environ. Qual. 25:334345.
Frink, C.R. and W.A. Norvell. 1984. Chemical and physical properties of Connecticut lakes. Conn. Agric. Exp. Sta. Bull. 817.

Baystate Environmental Consultants Inc. 1992. A review of the Bantam Lake improvement project: 1981-1991. 296 North Main St., East Longmeadow, MA 01028

Muenscher, W.C. 1944. Aquatic Plants of the United States, Ithaca, New York, USA. Comstock Publishing Company Inc. Cornell University

Connecticut Department of Environmental Protection. 1995. Control of waterweeds and algae. Pesticide Management Division, 79 Elm St. Hartford, CT 06106-5127.

Green, R.W. and H.E. Westerdahl. 1990. Response of Eurasian Watermilfoil to 2,4-D concentrations and exposure times. J. Aquat. Plant Manage. 28:27-32.

Madsen, J.D, L.W. Eichler and C.W. Boylen. 1988. Vegetative spread of Eurasian watermilfoil in Lake George, New York. J. Aquat. Plant Manage. 26:47-50

Madsen, J.D., J.W. Sutherland, J.A. Bloomfield, L.W. Eichler, and C.W. Boylen. 1991. The decline of native vegetation under dense Eurasian watermilfoil canopies. J. Aquat. Plant Manage. 29:94-99.

Smith, C.S., T. Chand, R.F. Harris and J.H. Andrews. 1989. Colonization of a submersed aquatic plant, Eurasian milfoil (Myriophyllum spicatum), by fungi under controlled conditions. Appl. Environ. Microbiol. 55(9): 2326-2332.

Standifer, N.E. and J.D. Madsen. 1997. The effect of drying period on the germination of Eurasian watermilfoil seeds. J. Aquat. Plant Manage. 35:35-36.

Vallentyne, J.R. 1974. The algal bowl: Lakes and man. Department of the Environment, Fisheries and Marine Service. Ottawa, Canada 


\section{NOTES}





\footnotetext{
The Connecticut Agricultural Experiment Station (CAES) prohibits discrimination in all its programs and activities on the basis of race, color, ancestry, national origin, sex, religious creed, age, political beliefs, sexual orientation, criminal conviction record, genetic information, learning disability, present or past history of mental disorder, mental retardation or physical disability including but not limited to blindness, or marital or family status. To file a complaint of discrimination, write Director, The Connecticut Agricultural Experiment Station, P.O. Box 1106, New Haven, CT 06504, or call (203) 974-8440. CAES is an equal opportunity provider and employer. Persons with disabilities who require alternate means of communication of program information should contact the Chief of Services at (203) 974-8442 (voice); (203) 974-8502 (FAX); or Michael.Last@po.state.ct.us (E-mail).
} 


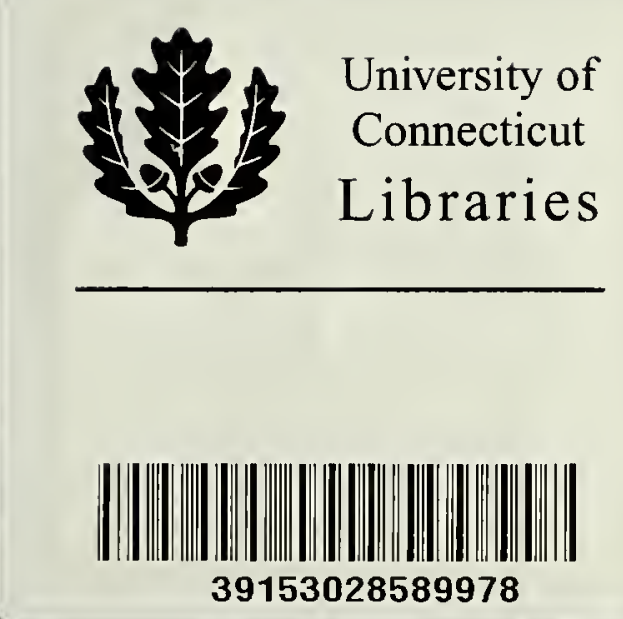


